University of Nebraska - Lincoln

DigitalCommons@University of Nebraska - Lincoln

\title{
Land Surface Dynamics in Kazakhstan: Dynamic Baselines and Change Detection
}

\author{
Geoffrey M. Henebry \\ University of Nebraska-Lincoln, geoffrey.henebry@sdstate.edu \\ Kirsten M. de Beurs \\ University of Nebraska-Lincoln \\ Anatoly A. Gitelson \\ University of Nebraska-Lincoln, agitelson2@unl.edu
}

Follow this and additional works at: https://digitalcommons.unl.edu/natrespapers

Part of the Natural Resources and Conservation Commons

Henebry, Geoffrey M.; de Beurs, Kirsten M.; and Gitelson, Anatoly A., "Land Surface Dynamics in Kazakhstan: Dynamic Baselines and Change Detection" (2002). Papers in Natural Resources. 231. https://digitalcommons.unl.edu/natrespapers/231

This Article is brought to you for free and open access by the Natural Resources, School of at DigitalCommons@University of Nebraska - Lincoln. It has been accepted for inclusion in Papers in Natural Resources by an authorized administrator of DigitalCommons@University of Nebraska - Lincoln. 


\title{
Land Surface Dynamics in Kazakhstan: Dynamic Baselines and Change Detection
}

\author{
Geoffrey M. Henebry \\ University of Nebraska-Lincoln/CALMIT \\ 113 Nebraska Hall \\ Lincoln, NE 68588-0517 USA \\ T: 402-472-6158 F: 402-472-4608 \\ email: ghenebry@calmit.unl.edu \\ Kirsten M. de Beurs \\ University of Nebraska-Lincoln/CALMIT \\ email: kdebeurs@calmit.unl.edu \\ Anatoly A. Gitelson \\ University of Nebraska-Lincoln/CALMIT \\ email: gitelson@calmit.unl.edu
}

\begin{abstract}
Analysis of the spatio-temporal structure of NDVI in the Pathfinder AVHRR Land data set for Kazakhstan from 1981-1999 reveals significant changes in the distributions of the scale of fluctuation (SOF) before and after 1992 in some ecoregions at certain phases of the growing season. These differences are likely due to actual influences on the land surface and not changes in sensor characteristics. Further analysis is required to identify and quantify these influences.
\end{abstract}

\section{INTRODUCTION}

The Republic of Kazakhstan is the ninth largest country in the world, the largest country in Central Asia and, after Russia, the largest of the Independent States formed after the Soviet Union's collapse. The country is mostly rangeland: cattle, sheep, goats, and other livestock graze almost $70 \%$ of the land area. Since the abrupt institutional changes surrounding the disintegration of the Soviet Union in the early 1990s, Kazakhstan has undergone extensive land-cover changes. A recent official study suggests two-fold decreases in agricultural lands and state holdings and a nine-fold increase in settled areas after 1992 (the year the Republic of Kazakhstan was formed). Marked decreases in livestock and meat production suggest that institutional change and its socio-economic consequences are primary drivers of the region's land-cover change. Are these changes in agricultural production detectable in coarse spatial resolution image time series? Few details are known about the pace or extent of land cover change, due to the collapse of regional environmental monitoring networks in the early 1990s. To be able to assess the significance of changes in vegetation indices, it is necessary to examine the observational record and place this episode within the larger context of climatic variability and landscape dynamics.

\section{STUDY AREA}

At 2.72 million $\mathrm{km}^{2}$, Kazakhstan is more than one-third the size of the conterminous US or roughly equal in area to all of Western Europe including the British Isles. It is bounded by
China on the east, Kyrgyzstan and Uzbekistan on the south, the Caspian Sea and a small section of Turkmenistan in the west, and Russia in the north. The northern part of Kazakhstan has very fertile soils that are intensively cultivated with spring wheat and other cereal grains. In the south, cotton, fruits, and vegetables are cultivated under irrigation. Most of the country, however, is used for grazing by sheep and cattle.

The climate of Kazakhstan is strongly continental. Annual precipitation ranges from about $250 \mathrm{~mm}$ in the north to 450 $\mathrm{mm}$ in the mountain ranges in the south, with much lower levels in the low-lying deserts. Temperature fluctuates widely with large variations between subregions, average temperature in January ranges from $-20^{\circ} \mathrm{C}$ in the northern and central regions to $-5^{\circ} \mathrm{C}$ in the south. Average July temperature in the north reaches $+18^{\circ} \mathrm{C}$ and $+29^{\circ} \mathrm{C}$ in the south [1].

\section{DATA}

For this study the Pathfinder AVHRR Land (PAL) 10-day NDVI composites from 7/81-12/99 were used to characterize the spatiotemporal dynamics of the land surface. We examined a seasonal subset of the image time series that ranged from April through September. Data are missing in the last two dekads of September 1994, due to sensor failure.

\section{METHODS}

\section{A. Image Classification}

To segment Kazakhstan into broad ecoregions, the image time series from May through September (276 image dates) was submitted to an unsupervised K-means clustering $(\Delta=0.05$, iter $=3)$. All April images $(n=54)$ were excluded due to high interannual variation in extent of snow cover. Three ecoregions were obtained: North, West, and South (Fig. 1).

\section{B. Scale of Fluctuation}

The spatial dependence structure of NDVI was estimated by scale of fluctuation (SOF) analysis using random walk 
resampling $[2,3]$ for the entire country and each of three ecoregions. A stopping criterion of $5 \%$ and $10^{4}$ random walks were used for each image date. Results were summarized using simple descriptive statistics: mean, median, coefficient of variation, interquantile range, etc. We present here only results for mean NDVI and mean SOF.

\section{Histograms and Statistical Tests}

Histograms were calculcated for mean SOF and NDVI for the complete image and for the different regions. To test for significant differences in the data distributions before and after 1992, three statistical tests were performed: MannWhitney, F, and Student's t. Due to seasonal patterns, the histograms for the three ecoregions exhibited bimodality. The descriptive statistics for each ecoregion were divided into two periods. For North and South, the data were split at the end of June at day of year (DOY) 170. The growing season was less pronounced and peaked earlier in the West; therefore, the data were split at DOY 160 . The aim of these temporal division was to obtain unimodal distributions. KolmogorovSmirnov tests showed normality for all data following the splits, except for two conditions: (1) in the South, in the later growing season, after 1992; and (2) in the West, in the early growing seasons, before 1992. Tests that assume normality (F and Student's t) can be used in all other cases.

\section{RESULTS AND DISCUSSION}

Mean NDVI for the entire country and each ecoregion can be seen in Fig. 2. NDVI increases quickly at the beginning of the growing season with the first peak in the South. In the North, there is steady increase until DOY 160 , followed by a gradual decline; this ecoregion has the largest influence on the NDVI seasonality for the entire country. The deserts that dominate the West show little temporal variation in NDVI. Fig. 3 shows the mean SOF. The temporal profile of SOF is of more interest than the value itself. SOF peaks in the early season in the South and, to a lesser degree, in the West and then declines. In the North, SOF decreases as NDVI increases but just prior to peak NDVI, SOF starts to increases until it stabilizes about DOY 190 or one month after peak NDVI.

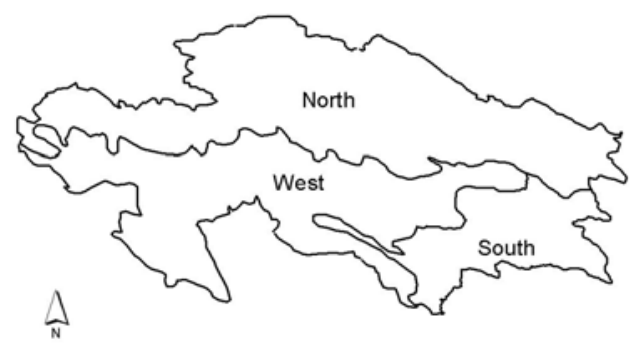

Fig. 1. The three regions in Kazakhstan.

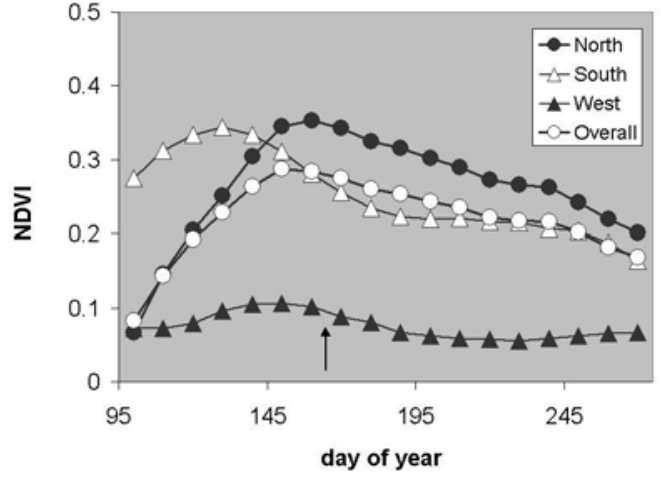

Fig. 2. NDVI in all the regions during the growing season.

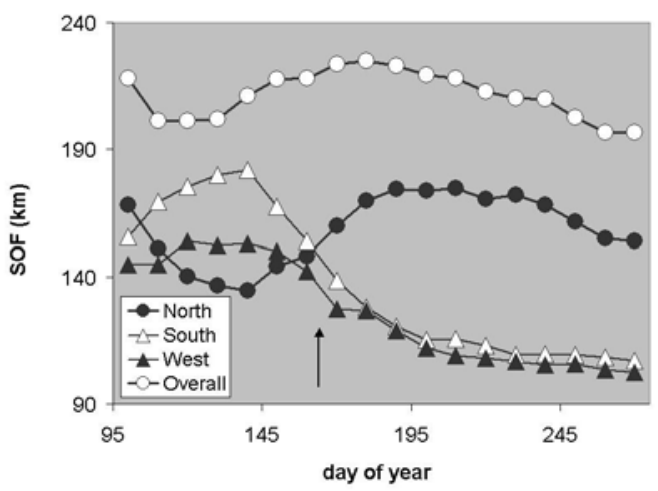

Fig. 3. SOF in all the regions during the growing season.

When tested separately at the level of the entire country and each ecoregion, no statistically significant differences were detected in comparisons before and after 1992 for either mean NDVI or SOF. Fig. 4 shows the SOF histogram for the South, which exhibited the most pronounced bimodality. Figs. 5 and 6 show SOF histograms that result from the division of the growing season.

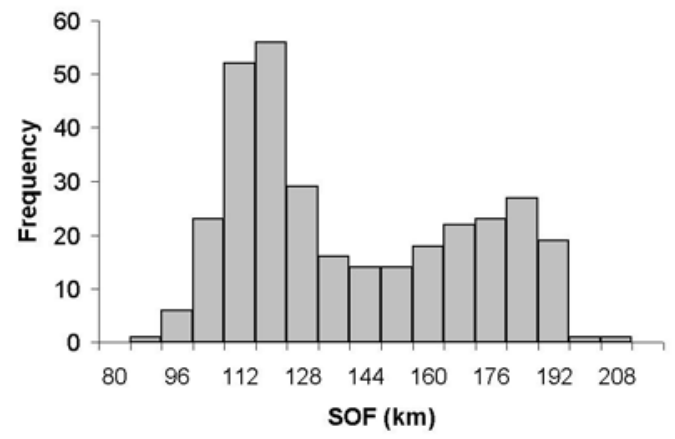

Fig. 4. SOF histogram for South in period DOY 110-270. 


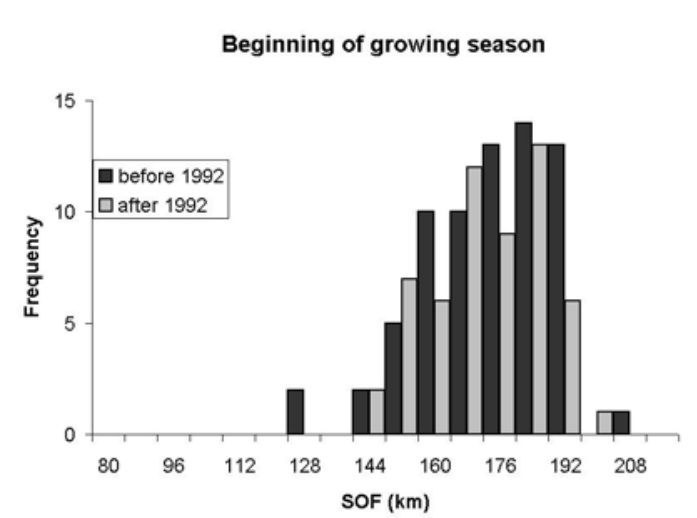

Fig. 5. Split SOF histogram for South in period DOY 110-160.

Late in growing season

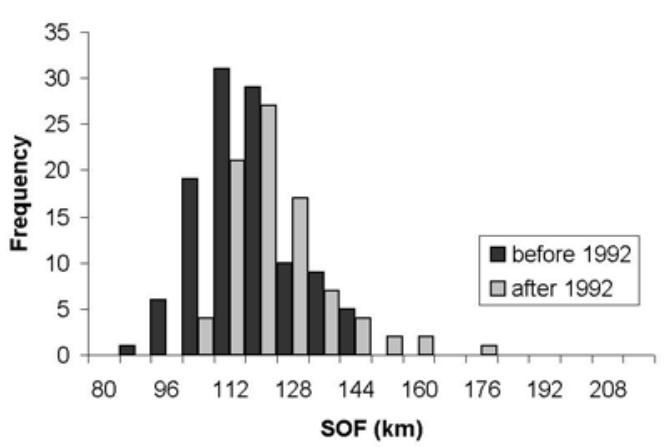

Fig. 6. Split SOF histograms for South in period DOY 170-270

In the early growing season, there is a significant difference in SOF detected in the North before and after 1992 (Table 1). This difference is significant at the $\mathrm{p}=0.1$ level with all three tests. No significant differences are apparent in the other ecoregions in the early growing season (Table 1). In the latter part of the growing season, there are significant differences in SOF detected in each ecoregion by the nonparameteric test and in the North and West using Student's t-test (Table 2). However, the F test fails to find significant differences in the variance of the distributions before and after 1992.

Thus, the spatial structure of NDVI, as measured by SOF, shows significant changes before and after 1992 in some ecoregions at some time periods.

TABLE 1

DifFerenCes IN SOF BEFORE AND AFTER 1992 (DOY 110 - 150/160)

\begin{tabular}{llll}
\hline Ecoregion & Mann-Whitney & F-test & Student t \\
\hline North & $\mathbf{0 . 0 3}$ & $\mathbf{0 . 0 6}$ & $\mathbf{0 . 0 8}$ \\
South & 0.254 & 0.40 & 0.59 \\
West & 0.37 & na & na \\
\hline
\end{tabular}

TABLE 2

DifFerENCES IN SOF BEFORE AND AFTER 1992 (DOY 160/170-270)

\begin{tabular}{llll}
\hline Ecoregion & Mann-Whitney & F-test & Student t \\
\hline North & $<\mathbf{0 . 0 1}$ & 0.69 & $<\mathbf{0 . 0 1}$ \\
South & $<\mathbf{0 . 0 1}$ & na & na \\
West & $\mathbf{0 . 0 3}$ & 0.20 & $\mathbf{0 . 0 3}$ \\
\hline
\end{tabular}

\section{CONCLUSIONS}

To what extent are these observed differences attributable to changes in satellites as opposed to land cover? To what extent are changes in land cover attributable to institutional changes as opposed to interannual climatic variation? These are not easy questions to answer unequivocally. However, it is significant to note that the NDVI data exhibit clear differences before and after 1992 in each ecoregion and for the entire country (data not shown). These differences in NDVI are expected given the well-documented peculiarities of the PAL data set, including satellite changes and solar azimuthal angles (SZA) [4]. Were the observed differences in the spatio-temporal structure of NDVI attributable solely to changes in satellites or SZA or even volcanic eruptions, then the differences should be observed consistently across ecoregions and across the growing season. However, what we observe is that the magnitude and significance of the changes in spatial structure of NDVI depend upon the ecoregions and the time of year. SOF is to some degree robust in the face of changes in sensor characteristics because it describes the relationship between neighboring pixels rather than comparing pixel values through time [2,3,5]. However, to assess the magnitude and significance of the changes in the SOF of NDVI and to attribute these changes to specific influences will require further attention to specific seasonal and regional trajectories.

\section{ACKNOWLEDGMENTS}

Research supported through the NASA LCLUC program. Image data used here were produced through funding from the EOS Pathfinder Program of NASA's Mission to Planet Earth in cooperation with NOAA. The data were provided by EOSDIS DAAC at Goddard Space Flight Center, which archives, manages and distributes this data set.

\section{REFERENCES}

[1] B.K. Esekin, et al., "Kazakhstan, State of the Environment", National Environmental Center for Sustainable Development of the Republic of Kazakhstan 2000. www.grida.no/enrin/htmls/kazahst/soe2/index.htm.

[2] G.M. Henebry, "Detecting change in grasslands using measures of spatial dependence with Landsat TM data", Remote Sensing of Environment, vol. 46, pp. 223-234.

[3] G.M. Henebry and D.G. Goodin, "Spatio-temporal analysis of landscape dynamics from image time series", unpublished $m s$ in review.

[4] R.K. Kaufman, et al. "Effect of orbital drift and sensor changes on the time series of AVHRR vegetation index data”, IEEE Transactions on Geoscience and Remote Sensing, vol. 38, no.6, pp. 2584-2597, November 2000.

[5] G.M. Henebry and H. Su. "Using landscape trajectories to assess the effects of radiometric rectification", International Journal of Remote Sensing vol. 14, no. 12, pp. 2417-2423, 1993. 